\title{
Filterability of Erythrocytes and Whole Blood in Preterm and Full-Term Neonates and Adults
}

\author{
OTWIN LINDERKAMP, BERNHARD J. HAMMER, AND ROLF MILLER \\ Department of Pediatrics, University of Heidelberg, Heidelberg, Federal Republic of Germany
}

\begin{abstract}
Filtration techniques are widely used to assess red blood cell (RBC) deformability and flow behavior of $\mathrm{RBC}$ in microcirculation. In this study filtration rates of RBC from 10 very low birth weight infants (24-30 wk gestation), 10 more mature preterm infants (31-36 wk gestation), 10 full-term neonates, and 10 adults were measured by using Nucleopore filters with pore diameters of 5 $\mu \mathrm{m}$ and filtration pressures of $1,2,5$, and $10 \mathrm{~cm} \mathrm{H}_{2} \mathrm{O}$. The major results follow: 1) At each of four filtration pressures, filtration rates of washed $\mathrm{RBC}$ were significantly $(p<$ $0.05)$ lower in the preterm infants than in the term neonates who in turn showed lower values than adults. The differences among the four groups became less as the pressure was increased from 1 to $10 \mathrm{~cm} \mathrm{H}_{2} \mathrm{O} .2$ ) The filtration rates increased with decreasing MCV $(r=-0.86)$. 3) The filter flow resistance (computed as ratio of filtration pressure and filter flow rate) decreased as the filtration pressure was raised from 1 to $10 \mathrm{~cm} \mathrm{H}_{2} \mathrm{O}$. The largest drop, $31 \%$ $(p<0.05)$, was observed in the most immature infants, the smallest, $10 \%(p>0.05)$, was seen in adults. 4) At a pressure of $1 \mathrm{~cm} \mathrm{H}_{2} \mathrm{O}$ the calculated mean transit time for RBC through the 5- $\mu \mathrm{m}$ pores was on an average 3.7 times longer in the smallest preterm infants than in the adults $(19.7 \pm 7.8$ and $5.3 \pm 1.4 \mathrm{~ms}$, respectively), whereas the factor was only 2.7 at a pressure of $10 \mathrm{~cm} \mathrm{H}_{2} \mathrm{O}(13 \pm 0.4$ and $0.5 \pm 0.1 \mathrm{~ms}$, respectively). 5) Filtration rates of whole blood were determined at a pressure of $10 \mathrm{~cm} \mathrm{H}_{2} \mathrm{O}$. These filtration rates were significantly $(p<0.05)$ less compared with filtration rates of washed $\mathrm{RBC}$. The largest difference was observed in the smallest preterm infants $(-77 \%)$, the smallest difference in adults $(-41 \%)$. In conclusion, the filtration rate of $\mathrm{RBC}$ from preterm and term neonates may be lower than that of adults because of the larger size of neonatal RBC. At high pressure, filterability of neonatal RBC improves, possibly because of decreased resistance of neonatal RBC to elastic deformation. Filtration of whole blood from neonates may, in addition, be impaired because of the higher number of poorly deformable leukocytes and erythroblasts. (Pediatr Res 20:1269-1273, 1986)
\end{abstract}

\section{Abbreviations}

RBC, red blood cells

PBS, phosphate buffered saline

$\mathrm{MCV}$, mean corpuscular volume
Received April 2, 1986; accepted July 22, 1986

Reprints O. Linderkamp, M.D. Universitäts-Kinderklinik Heidelberg, Im Neuenheimer Feld 150, D-6900 Heidelberg, Federal Republic of Germany.

This work was supported by Research Grant Li 291/4 from the Deutsche Forschungsgemeinschaft.
Hyperviscosity in neonates is a frequent and potentially serious condition, which may cause circulatory failure and impaired microcirculation in various vital organs (1). Blood viscosity is mainly determined by hematocrit. However, decreased RBC deformability can also contribute to an increase in blood viscosity. At high hematocrit, the deformability of RBC is particularly crucial because blood viscosity exhibits a larger increase with increasing hematocrit when RBC deformability is impaired (2). Moreover, decreased RBC deformability may hinder the entry of 8- $\mu \mathrm{m}$ diameter RBC into capillaries with diameters of 3-4 $\mu \mathrm{m}$ (3), slow down oxygen uptake and release in capillaries (4), and block the passage through narrow splenic slits, thereby aiding in destruction of RBC by immunological mechanisms (5). Decreased RBC deformability has been observed in neonates with severe septicemia, necrotizing enterocolitis (6), and vitamin $\mathrm{E}$ deficiency (7). The markedly shortened life-span of neonatal RBC (8) has also been referred to impaired RBC deformability $(9,10)$. This explains the great interest in the measurement of $\mathrm{RBC}$ deformability in neonates.

Filtration techniques are widely used to assess RBC deformability because they can be performed without a special apparatus. Moreover, RBC filterability is regarded as a model of in vivo microcirculation (11). However, RBC filterability depends on several factors $(2,11-13)$ : 1) RBC deformability (i.e. shape change in response to a given force), 2) RBC size (i.e. necessary deformation for entry into a filter pore), 3) presence of large rigid particle (i.e. leukocytes and RBC aggregates, and 4) filtration pressure. These factors must be considered if filtration studies are performed.

Most studies on the filtration rate of $\mathrm{RBC}$ from term neonates have shown that neonatal RBC are less filterable than adult RBC (9-11, 14, 15). However, Bergqvist et al. (16) found no difference in filterability between RBC from term neonates and adults possibly because they used a very high filtration pressure of 34 $\mathrm{cm} \mathrm{H}_{2} \mathrm{O}$. Two papers reported inverse relationships between filtration rate and $\mathrm{MCV}$ of $\mathrm{RBC}$ from term neonates and adults $(9,15)$. Buchan $(14)$ measured lower filtration rates in preterm infants with gestational age of 34-37 wk. In a preliminary report, Holland et al. (17) described decreased filterability of RBC from preterm infants with gestational age of 27-35 wk. However, in both studies RBC were examined without eliminating leukocytes. Since the resistance of leukocytes to filtration through $5-\mu \mathrm{m}$ pores is 1000 times more than that of RBC (13), these previous studies cannot distinguish between $\mathrm{RBC}$ and leukocyte filterability (2).

The present study was designed to measure filtration rates of $\mathrm{RBC}$ from newborn infants with gestational ages of 24-41 wk and from adults by using filtration pressures of $1,2,5$, and 10 $\mathrm{cm} \mathrm{H}_{2} \mathrm{O}$. Furthermore, we determined the influence of plasma and leukocytes on filtration rates.

\section{MATERIALS AND METHODS}

Study population and blood samples. Placental blood samples from 30 newborn infants were studied with approval of the 
Department of Pediatrics Human Subjects Research Committee. Ten were healthy full-term infants with gestational ages of 38$41 \mathrm{wk}$ and birth weights of $3250-3640 \mathrm{~g} ; 10$ were preterm infants with gestational ages of 24-30 wk and birth weights of 780-1410 $\mathrm{g}$; and 10 had gestational ages of 31-36 wk and birth weights of 1400-2590 g. Infants with malformations, erythroblastosis, diabetic mothers, hemorrhage, perinatal asphyxia, and caesarean section were excluded, as were twins and infants with proven infection or high risk of infection. All infants had birth weights appropriate for gestational age (10th-90th percentile according to unpublished Munich charts).

For the 30 neonates, $10-20 \mathrm{ml}$ blood were collected from the placenta into EDTA $(1 \mathrm{mg} / \mathrm{ml})$ immediately after cord clamping before delivery of the placenta. Adult blood samples were collected from 10 healthy hospital personnel via venipuncture into EDTA. All measurements were made within $4 \mathrm{~h}$ after collection (18). Part of each whole blood sample was diluted with cell-free autologous plasma at a hematocrit of $10 \%$ to assess the influence of nucleated cells (i.e., leukocytes and erythroblasts) on the filtration rates. Note that the nucleated cells were diluted in proportion to the hematocrit, which varied moderately among the four groups (Table 1). Another part of each blood sample was centrifuged at $2,000 \times g$ for $10 \mathrm{~min}$, and, via gentle aspiration, the plasma was removed and the buffy coat discarded. The $\mathrm{RBC}$ were washed three times in an isotonic PBS solution $(0.122$ $\mathrm{mol} / \mathrm{l} \mathrm{NaCl}, 0.030 \mathrm{~mol} / 1 \mathrm{KH}_{2} \mathrm{PO}_{4}+\mathrm{Na}_{2} \mathrm{HPO}_{4} ; 290 \mathrm{mosmol} / \mathrm{kg}$, $\mathrm{pH} 7.42$ at $25^{\circ} \mathrm{C}$ ) containing $2 \mathrm{~g} / 1$ of human serum albumin. Albumin was added to prevent echinocytic transformation of red blood cells. After the last wash, RBC was resuspended in the PBS albumin at a hematocrit of $10 \%$. These suspensions contained fewer than 100 leukocytes and erythroblasts per microliter (i.e., $<1$ nucleated cell/10,000 RBC).

Filtration method. The filtration technique described by Schmid-Schönbein et al. (11) was used (equipment available through Effenberger, Munich, FRG). The filter holder consists of three parts. The upper part, which has the form of a funnel, is filled with $2 \mathrm{ml}$ of sample and is connected to compressed air. The middle part is shaped like a flat dome and contains the filter with a filtration area of $0.385 \mathrm{~cm}^{2}$. The lower part is aerated and collects the filtrate. The whole filter chamber is watertight and is inserted into a thermocontrolled water bath $\left(37^{\circ} \mathrm{C}\right)$. Six of these chambers can be used simultaneously. HemafilNucelopore filters with 5- $\mu \mathrm{m}$ diameter pores (Nucleopore Corp., Pleasanton, CA) were used. Positive pressures of $1,2,5$, and $10 \mathrm{~cm} \mathrm{H}_{2} \mathrm{O}$ were applied using compressed air and a water manometer. Filtration rates of $\mathrm{RBC}$ in plasma suspensions were measured by using only one pressure of $10 \mathrm{~cm} \mathrm{H}_{2} \mathrm{O}$ since initial studies in our laboratory indicated that filters may become clogged at lower pressure if leukocytes have not been removed. The filtration time of $2 \mathrm{ml}$ of the cell suspension with a hematocrit of $10 \%$ was measured by using a stopwatch. The filtration rate of $\mathrm{RBC}$ (in $\mu \mathrm{l} / \mathrm{s} / \mathrm{cm}^{2}$ filter area) was calculated as the ratio of filtered $\mathrm{RBC}$ (i.e. $0.2 \mathrm{ml}$ of $\mathrm{RBC}$ ) and the product of the filtration time and the filter area $\left(0.385 \mathrm{~cm}^{2}\right)$. In each measurement, the testing of RBC suspension was preceded by passing the suspending medium (PBS or plasma, respectively) through the same filter $(11-13)$. Each filter was used for only one RBC suspension at one pressure. Thus 10 filters were used for each blood sample.

The mean transit time $\left(\mathrm{T}_{\mathrm{c}}\right)$ for a single $\mathrm{RBC}$ to pass through a pore was calculated from a formula derived from that given by Kikuchi et al. (19)

$$
\mathrm{T}_{\mathrm{c}}=\operatorname{AdV}_{\mathrm{c}}\left[1 / \mathrm{F}_{\mathrm{c}}+\left(1 / \mathrm{F}_{\mathrm{b}}\right)\left(1-1 / \mathrm{h}+\mathrm{V}_{\mathrm{p}} / \mathrm{V}_{\mathrm{c}}\right)\right]
$$

Where $A$ is effective filtration area $\left(0.385 \mathrm{~cm}^{2}\right), \mathrm{d}$ is pore density $\left(4 \times 10^{5} \mathrm{~cm}^{-2}\right), \mathrm{h}$ is hematocrit $(0.11 / 1), \mathrm{V}_{\mathrm{p}}$ is mean pore volume $(255.3 \mathrm{fl}), \mathrm{V}_{\mathrm{c}}$ is mean corpuscular volume (MCV in $\left.\mathrm{fl}\right), \mathrm{F}_{\mathrm{b}}$ is buffer flow rate (in $\mu \mathrm{l} / \mathrm{s}$ ) determined for each filter, $\mathrm{F}_{c}$ is $\mathrm{RBC}$ flow rate (in $\mu \mathrm{l} / \mathrm{s}$ ), and $\mathrm{T}_{\mathrm{c}}$ is mean transit time (in $\mathrm{ms}$ ) for a single $\mathrm{RBC}$. When the constant values are inserted into the equation it can be transformed into

$$
\mathrm{T}_{\mathrm{c}}=0.4 \mathrm{~V}_{\mathrm{c}}\left[1 / \mathrm{F}_{\mathrm{c}}+\left(1 / \mathrm{F}_{\mathrm{b}}\right)\left(255 / \mathrm{V}_{\mathrm{c}}-9\right)\right]
$$

General hematological methods. Hematocrit was measured by the microhematocrit method. The values were not corrected for trapped plasma, which is about $2 \%$ in full-term neonates and adults (17). RBC count, hemoglobin concentration, and white blood cell count were determined using a Coulter Counter (Coulter Electronics Inc., Harpenden, Herts, UK). Differential blood count was performed after Giemsa's stain for staining blood

\begin{tabular}{|c|c|c|c|c|c|c|}
\hline & \multirow[b]{2}{*}{$\begin{array}{l}\text { Filtration pressure } \\
\left(\mathrm{cm} \mathrm{H}_{2} \mathrm{O}\right)\end{array}$} & \multicolumn{3}{|c|}{ Neonates (wk of gestation) } & \multirow[b]{2}{*}{$\begin{array}{c}\text { Adults } \\
\text { D }\end{array}$} & \multirow[b]{2}{*}{$\begin{array}{l}\text { Significant differences } \\
\qquad(p<0.05)\end{array}$} \\
\hline & & $\begin{array}{c}\mathrm{A} \\
24-30 \\
\end{array}$ & $\begin{array}{c}\mathrm{B} \\
31-36 \\
\end{array}$ & $\begin{array}{c}\mathrm{C} \\
38-41 \\
\end{array}$ & & \\
\hline Hematocrit (\%) & & $43.5 \pm 2.2$ & $48.0 \pm 2.8$ & $49.4 \pm 4.7$ & $44.3 \pm 3.1$ & $\mathrm{~A}<\mathrm{C}>\mathrm{D} ; \mathrm{A}=\mathrm{B}=\mathrm{D}$ \\
\hline $\operatorname{MCV}(\mathrm{fl})$ & & $123.2 \pm 10.1$ & $117.2 \pm 7.8$ & $107.8 \pm 5.7$ & $90.1 \pm 4.9$ & $\mathrm{~A}=\mathrm{B}>\mathrm{C}>\mathrm{D}$ \\
\hline $\mathrm{MCH}(\mathrm{pg})$ & & $40.5 \pm 2.6$ & $38.5 \pm 2.2$ & $35.7 \pm 1.9$ & $29.9 \pm 1.9$ & $A=B>C>D$ \\
\hline $\mathrm{MCHC}(\mathrm{g} / \mathrm{dl})$ & & $32.6 \pm 1.7$ & $32.9 \pm 1.5$ & $33.0 \pm 1.5$ & $33.2 \pm 1.3$ & $\mathrm{~A}=\mathrm{B}=\mathrm{C}=\mathrm{D}$ \\
\hline Hemoglobin F (\%) & & $92.4 \pm 6.7$ & $85.7 \pm 6.1$ & $70.3 \pm 8.2$ & $0.8 \pm 0.4$ & $A=B>C>D$ \\
\hline Reticulocytes (\% RBC) & & $11.1 \pm 4.4$ & $6.8 \pm 2.9$ & $3.2 \pm 1.4$ & $1.1 \pm 0.3$ & $\mathrm{~A}>\mathrm{B}>\mathrm{C}>\mathrm{D} \dagger$ \\
\hline \multicolumn{7}{|l|}{ Nucleated cells } \\
\hline Erythroblasts (\% WBC) & & $70.3 \pm 56.7$ & $18.7 \pm 13.8$ & $6.3 \pm 2.8$ & $0.0 \pm 0.0$ & $\mathrm{~A}>\mathrm{B}>\mathrm{C}>\mathrm{D} \dagger$ \\
\hline $\mathrm{WBC}\left(\times 10^{9} / 1\right)$ & & $12.8 \pm 5.0$ & $11.5 \pm 4.3$ & $15.6 \pm 4.1$ & $6.2 \pm 1.7$ & $\mathrm{~A}=\mathrm{B}=\mathrm{C}>\mathrm{D} \dagger$ \\
\hline Segmented neutrophils (\%) & & $45.7 \pm 15.6$ & $48.5 \pm 16.2$ & $51.7 \pm 15.0$ & $53.5 \pm 11.6$ & $A=C=C=D$ \\
\hline Band and juvenile neutrophils (\%) & & $12.8 \pm 5.9$ & $7.5 \pm 3.6$ & $4.1 \pm 3.4$ & $0.5 \pm 0.3$ & $\mathrm{~A}>\mathrm{B}=\mathrm{C}>\mathrm{D} \dagger$ \\
\hline Eosinophils (\%) & & $0.5 \pm 0.4$ & $1.1 \pm 1.0$ & $1.7 \pm 1.5$ & $3.4 \pm 1.4$ & $\mathrm{~A}=\mathrm{B}=\mathrm{C}<\mathrm{D} \dagger$ \\
\hline Basophils (\%) & & $0.0 \pm 0.0$ & $0.1 \pm 0.2$ & $0.4 \pm 0.3$ & $0.7 \pm 0.4$ & $\mathrm{~A}=\mathrm{B}<\mathrm{C}<\mathrm{D} \dagger$ \\
\hline Lymphocytes (\%) & & $34.6 \pm 15.3$ & $37.0 \pm 17.6$ & $35.9 \pm 14.2$ & $36.4 \pm 7.2$ & $A=B=C=D$ \\
\hline Monocytes (\%) & & $6.4 \pm 4.5$ & $5.8 \pm 3.9$ & $6.2 \pm 3.7$ & $5.5 \pm 3.6$ & $\mathrm{~A}=\mathrm{B}=\mathrm{C}=\mathrm{D}^{\dagger}$ \\
\hline \multicolumn{7}{|l|}{ Filtration rates of $\mathrm{RBC}\left(\mu \mathrm{l} / \mathrm{s} / \mathrm{cm}^{2}\right)$} \\
\hline \multirow[t]{4}{*}{$\mathrm{RBC}$ in buffer } & 1 & $2.3 \pm 0.6$ & $2.9 \pm 0.6$ & $3.8 \pm 0.7$ & $5.0 \pm 0.8$ & $\mathrm{~A}=\mathrm{B}<\mathrm{C}<\mathrm{D}$ \\
\hline & 2 & $4.8 \pm 1.3$ & $5.9 \pm 1.3$ & $7.6 \pm 1.5$ & $10.3 \pm 1.5$ & $\mathrm{~A}=\mathrm{B}<\mathrm{C}<\mathrm{D}$ \\
\hline & 5 & $13.5 \pm 2.7$ & $15.9 \pm 3.0$ & $19.8 \pm 3.5$ & $26.3 \pm 3.8$ & $\mathrm{~A}=\mathrm{B}<\mathrm{C}<\mathrm{D}$ \\
\hline & 10 & $32.3 \pm 5.3$ & $36.8 \pm 5.9$ & $44.7 \pm 6.8$ & $55.3 \pm 7.9$ & $\mathrm{~A}=\mathrm{B}<\mathrm{C}<\mathrm{D}$ \\
\hline Whole blood & 10 & $7.2 \pm 2.9$ & $13.0 \pm 3.6$ & $20.9 \pm 5.2$ & $32.4 \pm 6.3$ & $\mathrm{~A}<\mathrm{B}<\mathrm{C}<\mathrm{D}$ \\
\hline
\end{tabular}

Table 1 . Hematological data and filtration rates of red cells and of whole blood*

* Values are means $\pm \mathrm{SD} ; n=10$ in each group. MCHC, mean corpuscular hemoglobin concentration; WBC, white blood cells.

$\dagger$ Friedman rank test. 
smear. Reticulocytes were counted after the staining of a blood smear by brilliant cresyl blue. Hemoglobin $F$ was quantified by the alkali denaturation test (20).

Statistics. A two-tailed paired $t$ test was used to test for differences between paired observations (e.g. filtration rates at different pressures). Differences among the four groups were tested using analysis of variance (21). A Friedman rank test was used when no normal distribution existed. Regression analyses were utilized to determine overall correlations between filtration rates, $\mathrm{MCV}$, hemoglobin $\mathrm{F}$, and reticulocyte count.

\section{RESULTS}

General data. MCV, mean corpuscular hemoglobin, hemoglobin $\mathrm{F}$, and reticulocyte count decreased throughout gestation and reached the lowest values in the adults (Table 1). Mean corpuscular hemoglobin concentration was similar in preterm infants, term neonates, and adults. Leukocyte and differential blood counts are shown in Table 1. Total neutrophils were about $55 \%$ in the four groups. However, the percentage of band neutrophils was higher in the smallest preterm infants and decreased as the gestational age increased.

Filtration studies. At each of the four filtration pressures, filtration rates of $\mathrm{RBC}$ in buffer suspensions were significantly lower in the preterm infants than in the term neonates who in turn showed lower values than the adults (Table 1). The differences depended on the filtration pressure: at a filtration pressure of $1 \mathrm{~cm} \mathrm{H}_{2} \mathrm{O}$, the RBC filtration rate in the adults was on an average $117 \%$ higher than in the smaller preterm infants, whereas the difference was only $71 \%$ at a pressure of $10 \mathrm{~cm} \mathrm{H}_{2} \mathrm{O}$.

Figure 1 shows the $\mathrm{RBC}$ filtration rates measured at a pressure of $1 \mathrm{~cm} \mathrm{H} \mathrm{H}_{2} \mathrm{O}$ plotted against the MCV. The inverse relationship was highly significant $(r=-0.86 ; p<0.001)$. Smaller correlation coefficients were found for the relationship between hemoglobin $\mathrm{F}$ and filtration rate $(r=-0.48)$ and between reticulocyte count and filtration rate $(r=-0.61)$. In all four groups, the filtration rates increased with increasing filtration pressure (Table 1). However, the rise in filtration rates was different among the four groups: As the pressure was increased from 1 to $10 \mathrm{~cm} \mathrm{H}_{2} \mathrm{O}$, the filtration rate increased by a factor of 15 in the smallest preterm infants, 13 in the larger preterm infants, 12 in the term neonates, and 11 in the adults.

Figure 2 shows the mean transit time for single RBC through filter pores. These mean transit times decreased with both increasing gestational age and increasing filtration pressure. The

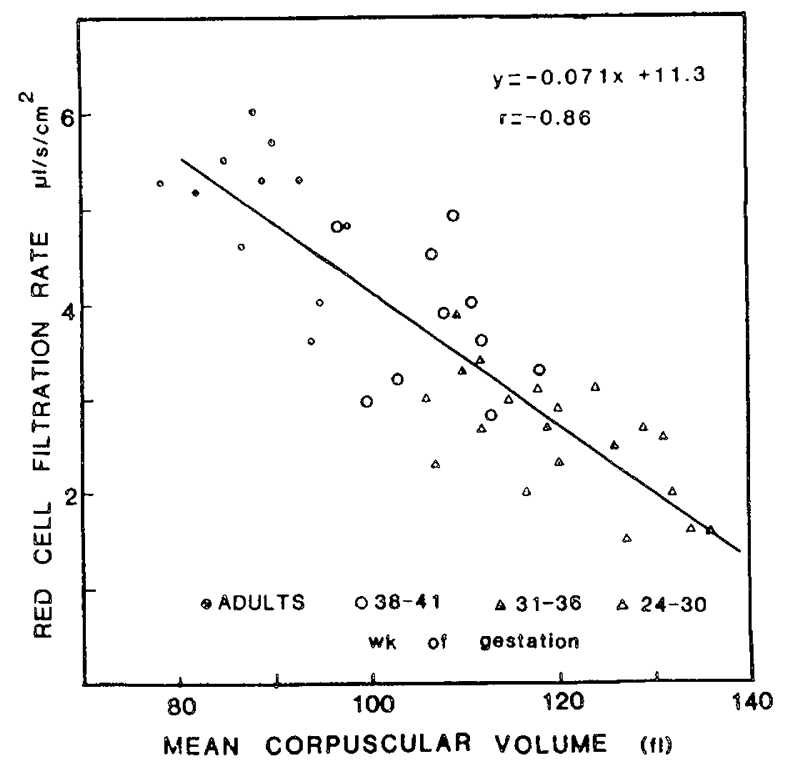

Fig. 1. Filtration rate of RBC (suspended in buffer at a hematocrit of $10 \%$ ) plotted against MCV. There was a highly significant inverse relationship.

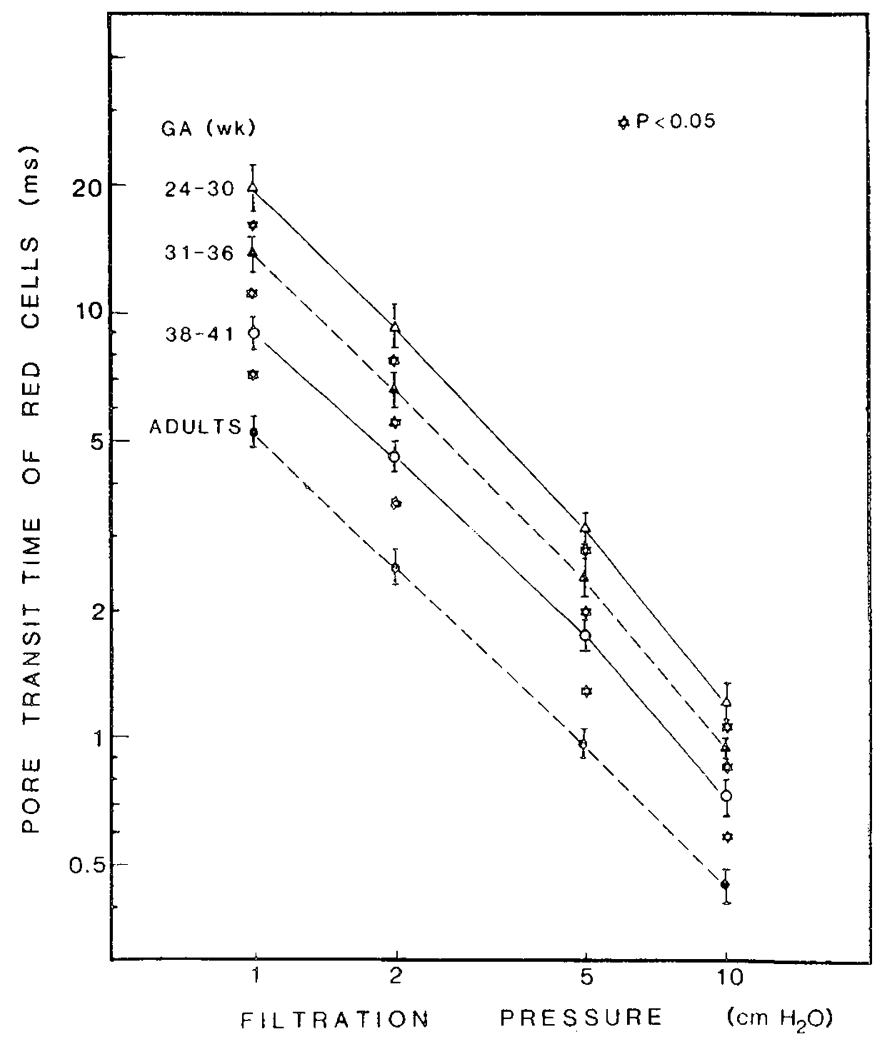

Fig. 2. Mean pore transit time of single RBC plotted against filtration pressure. Values are means \pm SD.

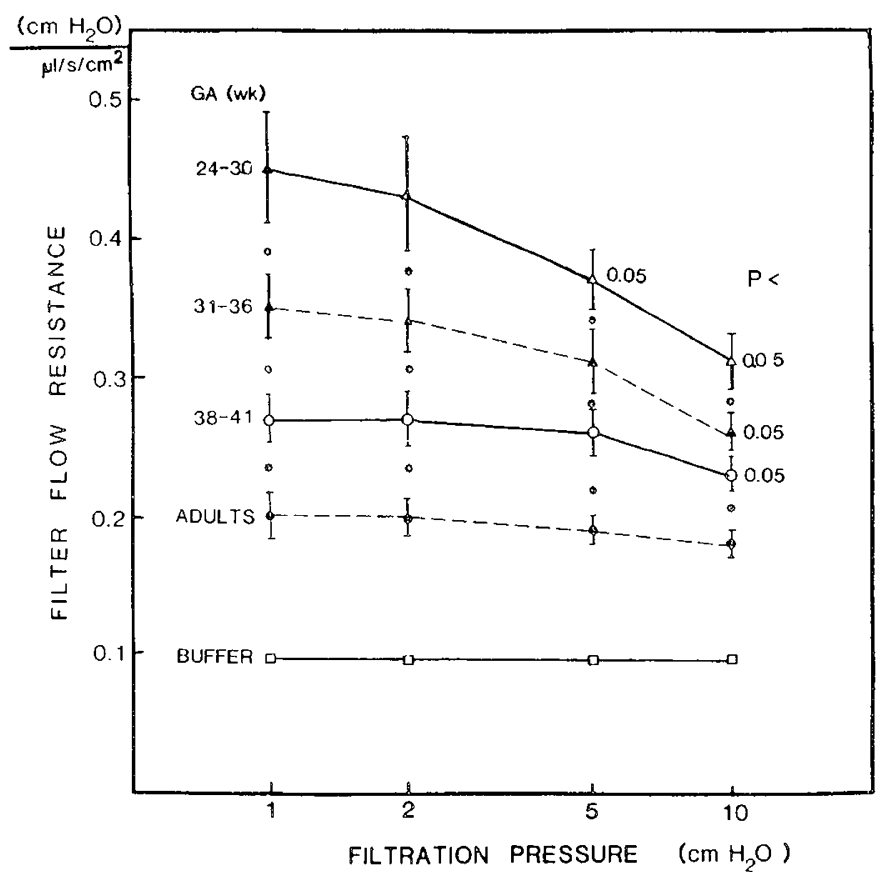

Fig. 3. Filter flow resistance (computed as ratio of filtration pressure and flow rate) of RBC plotted against filtration pressure. Values are means $\pm S D$. Note that resistance of $R B C$ from preterm infants decreased markedly as pressure was raised.

differences among the four groups were larger at lower filtration pressures than at high filtration pressures. At a filtration pressure of $1 \mathrm{~cm} \mathrm{H}_{2} \mathrm{O}, \mathrm{RBC}$ transit time was on an average 3.7 times longer in the smallest preterm infants than in the adults, whereas the facter was only 2.7 at a pressure of $10 \mathrm{~cm} \mathrm{H}_{2} \mathrm{O}$.

Figure 3 shows the filter flow resistance (computed as ratio of filtration pressure and filter flow rate). Flow resistance was significantly higher in the preterm infants compared with term 
neonates who in turn showed higher flow resistance than the adults. In the three neonatal groups, flow resistance decreased significantly $(p<0.05)$ as the filtration pressure was increased from 1 to $10 \mathrm{~cm} \mathrm{H}_{2} \mathrm{O}$. The largest drop, $31 \%$, was observed in the most immature infants, the smallest, $10 \%$, in adults. In the other groups the decrease was $26 \%$ (31-36 wk of gestation) and $15 \%$ (term neonates).

Filtration rates of whole blood were measured at a pressure of $10 \mathrm{~cm} \mathrm{H}_{2} \mathrm{O}$ (Table 1). The filtration rates were significantly $(p<$ 0.001 ) less compared with the filtration rates of RBC in buffer in all four groups. The largest difference was observed in the smallest preterm infants $(-77 \%)$, the smallest difference in adults $(-41 \%)$.

\section{DISCUSSION}

From the present data we reach four major conclusions: 1) at given pressure, $\mathrm{RBC}$ filtration rates through $5-\mu \mathrm{m}$ pores are lower, and mean RBC transit times are longer in preterm infants than in term neonates and adults; 2) slow RBC filtration rates in neonates are related to large cellular volume; 3 ) the filter flow resistance of $\mathrm{RBC}$ from preterm infants decreases more with increasing pressure than that of RBC from term neonates and adults; and 4) filterability of whole blood is markedly less than that of washed $\mathrm{RBC}$, particularly in preterm infants.

Previous RBC deformability studies using the rheoscope and viscometry techniques showed no meaningful differences among preterm infants with $24-36$ wk of gestational age, term neonates, and adults $(22,23)$. These data are not necessarily contradictory to the present results because $\mathrm{RBC}$ filtration rates are affected by factors that exert minor or no influence on rheoscope and viscometry results. These factors include: 1) RBC diameter and surface area (i.e. necessary RBC deformation), 2) presence of a small subpopulation of poorly deformable RBC, 3) pressure acting on the cells, and 4) presence of poorly deformable cells (e.g. leukocytes) and particles (e.g. RBC aggregates) (2, 11-13).

The ratio of $\mathrm{RBC}$ to pore diameter and the membrane surface area determine how much a cell has to deform to enter a pore. A small RBC with a diameter of $5 \mu \mathrm{m}$ does not need to deform to enter and pass a 5- $\mu \mathrm{m}$ pore, whereas a large cell has to deform markedly. Since cellular deformation requires time (24), the transit time of individual RBC through filter pores increases with increasing cellular volume (19), thereby decreasing the overall filtration rate. This explains the prolonged mean transit times and decreased filtration rates of the large $\mathrm{RBC}$ from preterm infants when compared with the smaller $\mathrm{RBC}$ from term neonates and adults (Figs. 1 and 2). The smallest cylindrical pore a $\mathrm{RBC}$ can enter without loss of volume is determined by the minimum cylindrical diameter of the cell. The average RBC from a term neonate has a minimum cylindrical diameter of $3.04 \pm 0.25 \mu \mathrm{m}$, whereas that of an adult $\mathrm{RBC}$ is $2.81 \pm 0.23$ $\mu \mathrm{m}$ (25). It can be calculated that even RBC with a volume of $200 \mathrm{fl}$ have a minimum cylindrical diameter of $<4 \mu \mathrm{m}$ so that all $\mathrm{RBC}$ from preterm and term neonates should be able to enter and pass $5-\mu \mathrm{m}$ pores without obstructing them.

The filtration technique is extremely sensitive to the presence of a small percentage of poorly deformable RBC that may gradually plug more pores, thereby hindering the passage of subsequent $\mathrm{RBC}$ and decreasing the overall filtration rate (2). A recent study has shown that blood from term and preterm neonates contains slightly larger numbers of poorly deformable $\mathrm{RBC}$ compared with adult blood (22). Moreover, reticulocytes are more resistant to passage of narrow micropipettes than mature RBC (26). Thus, both a small subpopulation of rigid $\mathrm{RBC}$ and a higher reticulocyte count (Table 1) may contribute to the decreased filtration rates of neonatal RBC.

$\mathrm{RBC}$ enter narrow channels (e.g. capillaries, pores) by membrane extension and folding. At low pressure, membrane extension prevails, whereas at higher pressure the whole cell folds (24). The pressure at which folding begins is important for the entrance behavior of $\mathrm{RBC}$, since the resistance to membrane folding is markedly less than the resistance to membrane extension. A recent study has shown that the membrane of neonatal $R B C$ extends slightly more in response to a given force and begins to fold at a lower pressure than the adult RBC (24). This may explain why the flow resistance of neonatal RBC dropped more than that of adult RBC with increasing filtration pressure (Fig. 3).

Leukocytes exert 700-1000 times more resistance to the passage of $5-\mu \mathrm{m}$ filter pores than RBC (12). Thus, if whole blood with a 1:1000 ratio of leukocytes to RBC is filtered through 5$\mu \mathrm{m}$ pores, about $50 \%$ of the flow resistance is provided by the leukocytes. In other words, the leukocytes in whole blood slow down filtration rates by about $50 \%$. This agrees with our finding from adult blood (Table 1). In the neonates, the presence of nucleated cells reduced the filtration rates more than in adults (Table 1). Possible explanations of this finding include the higher leukocyte and erythroblast count (Table 1), decreased deformability of neonatal granulocytes (27), and the presence of extremely rigid immature granulocytes (28).

Plasma could reduce filtration of RBC because of the higher viscosity of plasma compared with a buffer solution (23) and because plasma macroproteins (e.g. fibrinogen) cause RBC aggregation under low shear conditions (29). Both plasma viscosity and RBC aggregation are less in neonates than in adults as a result of low fibrinogen concentration in neonatal blood $(23,29)$. Thus, the presence of plasma proteins should decrease the differences in filtration rates between neonates and adults rather than increasing the differences as observed in the present study (Table 1). This points to a minor role of plasma proteins and to a major role of leukocytes in the filterability of RBC in plasma.

In conclusion, the filtration rate of $\mathrm{RBC}$ from preterm infants and term neonates may be decreased compared with adults because of the larger size of neonatal RBC and the presence of a small subpopulation of rigid cells (22). These disadvantages may be partially compensated by the decreased resistance of neonatal RBC to elastic deformation (24). Filtration of whole blood from preterm infants and term neonates may, in addition, be impaired because of the higher leukocyte and erythroblast count and decreased deformability of leukocytes.

Delayed entry time of neonatal RBC into filter pores suggests that the passage time through the small splenic slits is also prolonged (30). This could aid in the destruction of RBC by macrophages (5) and explain the shortened RBC survival time in neonates (8). In preterm infants, RBC life-span is even shorter than in term neonates (8), which agrees with our finding of decreased filterability of $\mathrm{RBC}$ from preterm infants when compared with term neonates (Table 1).

Decreased filterability of the large neonatal RBC could also imply impaired microcirculatory dynamics in narrow vessels. However, there is no evidence that neonatal RBC are indeed disadvantageous for adequate circulation since the circulation in the neonate is characterized by low vascular resistance and high flow conditions (31). Moreover, a recent study on newborn lambs suggests that polycythemia induced by adult RBC impedes pulmonary blood flow more than a similar polycythemia induced by neonatal RBC (32). However, it cannot be ruled out that large $\mathrm{RBC}$ with diminished deformability (e.g. in septicemia) (6) may impair circulation more than smaller RBC with poor deformability.

Acknowledgments. The authors thank Monika Günter for technical assistance, Liselotte Krüger for secretarial assistance, and Vivian M. Vargas, M.S.B.A., for help in preparing the manuscript.

\section{REFERENCES}

1. Black VD, Lubchenco LO 1982 Neonatal polycythemia and hyperviscosity. Pediatr Clin N Am 29:1137-1148

2. Chien S 1981 Determinants of blood viscosity and red cell deformability. Scand 
J Clin Lab Invest 40(suppl 156):7-12

3. La Celle PL 1975 Pathologic erythrocytes in the capillary microcirculation. Blood Cells 1:269-283

4. Kon K, Maeda N, Shiga T 1983 The influence of deformation of transformed erythrocytes during flow on the rate of oxygen release. J Physiol (Lond) 339:573-584

5. Nash GB, Meiselman HJ 1981 Red cell ageing: changes in deformability and other possible determinants of in vivo survival. Microcirculation 1:255-284

6. Linderkamp O, Klose HJ, Betke K, Fuhrmann G, Galanos C, Kelson S, Marge W, Riegel KP 1980 Effect of neonatal sepsis, endotoxin and exchange transfusion on the deformability of red blood cells. Pediatr Res 14:1424(abstr)

7. Lubin B, Chiu D 1982 Properties of vitamin E-deficient erythrocytes following peroxidant injury. Pediatr Res 16:928-932

8. Pearson HA 1967 Life-span of the fetal red blood cell. J Pediatr 70:166-171

9. Gross GP, Hathaway WE 1972 Fetal erythrocyte deformability. Pediatr Res 6:593-599

10. Tillmann W, Zabel U, Lakomek M, Schröter W 1981 Influence of the fluidity of hemoglobin $F$ on the flexibility of red cells of newborn and older infants Bibl Anat 20:222-225

11. Schmid-Schönbein H, Weiss J, Ludwig H 1973 A simple method for measuring red cell deformability in models of the microcirculation. Blut 26:369-379

12. Chien S. Schmalzer EA, Lee MML, Impelluso T, Skalak R 1983 Role of white blood cells in filtration of blood cell suspensions. Biorheology 20:11-27

13. Jones JG, Holland BM, Humphrys J, Wardrop CA 1985 The flow of blood cell suspensions through $3 \mu \mathrm{m}$ and $5 \mu \mathrm{m}$ Nuclepore membranes: a comparison of kinetic analysis with scanning electron microscopic examinations. $\mathrm{Br}$ J Haematol 59:541-546

14. Buchan PC 1981 Fetal haemorheology in normal pregnancy. 2nd European Conference on clinical haemorheology, London 1981 (abstr 127)

15. Reinhart WH, Danoff SJ, King RG, Chien S 1985 Rheology of fetal and maternal blood. Pediatr Res 19:147-153

16. Bergqvist $G$, Bygdeman S, Rylander E 1977 Deformability of fetal erythrocytes. Bibl Anat 16:510-512

17. Holland BM, Humphrys J, Jones JG, Wardrop CAJ 1985 The influence of preterm delivery on red cell filterability in neonates-inferences as to pathogenesis of clinical complications of prematurity. Pediatr Res 19:1129(abstr)

18. Linderkamp O. Meiselman HJ, Wu PYK, Miller FC 1981 Blood and plasma viscosity and optimal hematocrit in the normal newborn infant. Clin He- morheol 1:575-584

19. Kikuchi Y, Horimoto M, Koyama T, Koyama Y, Tozawa S 1980 Estimation of pore passage time of red blood cells in normal subjects and patients with renal failure. Experientia 36:325-327

20. Betke K, Marti H, Schlicht I 1959 Estimation of small percentage of foetal haemoglobin. Nature 184:1877-1878

21. Campbell RC 1967 Statistics for Biologists. Cambridge University Press, London

22. Linderkamp O, Güntner M, Hiltl W, Vargas VM 1986 Erythrocyte deformability in the fetus, preterm and term neonate. Pediatr Res 20:93-96

23. Linderkamp O, Versmold HT, Riegel KP, Betke K 1984 Contributions of red cells and plasma to blood viscosity in preterm and full-term infants and adults. Pediatrics 74:45-51

24. Linderkamp O, Nash GB, Wu PYK, Meiselman HJ 1986 Deformability and intrinsic material properties of neonatal red blood cells. Blood 67:1244-1250

25. Linderkamp O, Wu PYK, Meiselman HJ 1983 Geometry of neonatal and adult red blood cells. Pediatr Res 17:250-253

26. Leblond PF, LaCelle PL, Weed RI 1971 Cellular deformability: a possible determinant of the normal release of maturing erythrocytes from the bone marrow. Blood 37:40-46

27. Miller ME 1979 Phagocytic function in the neonate: selected aspects. Pediatrics 64:709-712

28. Lichtmann MA 1970 Cellular deformability during maturation of the myeloblast. Possible role in marrow egress. N Engl J Med 283:943-948

29. Linderkamp O, Ozanne, P, Wu PYK, Meiselman HJ 1984 Red blood cel aggregation in preterm and term neonates and adults. Pediatr Res 18:13561360

30. Cokelet GR 1981 Dynamics of erythrocyte motion in filtration tests and in vivo flow. Scand J Clin Lab Invest 41(suppl 156):77-82

31. Wu PYK, Wong WH, Guerra G, Miranda R, Godoy RR, Preston B, Schoentgen S, Levan NE 1980 Peripheral blood flow in the neonate. 1. Changes in total, skin, and muscle blood flow with gestational and postnatal age. Pediatr Res 14:1374-1378

32. Fouron JC, Bard H, Riopel L, de Muylder X, van Ameringen MR, Urfer F 1985 Circulatory changes in newborn lambs with experimental polycy themia: comparison between fetal and adult type blood. Pediatrics 75:10541060 